\title{
EKONOMIA POLITYCZNA PANDEMII. CZY KRYZYS ZAGROZI WSPÓŁCZESNEMU KAPITALIZMOWI?
}

\author{
POLITICAL ECONOMY OF PANDEMIC: \\ WILL THE CRISIS THREATEN CONTEMPORARY CAPITALISM? \\ Sławomir Czapnik*๑, Magdalena Ozimek-Hanslik**
}

\begin{abstract}
- ABSTRAKT
Tezą artykułu jest twierdzenie, iż obecna sytuacja kryzysowa w obszarze zdrowia publicznego nie musi oznaczać analogicznego kryzysu w sferze gospodarczej, czyli kapitalizmu neoliberalnego. Zakładamy, że obecna sytuacja, jaką stanowią warunki pandemiczne, współgra $\mathrm{z}$ gospodarką kapitalistyczną, wskutek czego system ten jawi się jako stabilny i efektywny jednocześnie.

W naszym artykule prezentujemy dialektyczny ogląd ideologicznych aspektów pandemicznej rzeczywistości, który koreluje z twierdzeniem o uspołecznieniu kosztów i prywatyzacji zysków procesów ekonomiczno-politycznych.
\end{abstract}

Słowa kluczowe: neoliberalizm; doktryna szoku; kapitalizm nadzoru; Covid-19; gender; nierówności społeczne
The thesis of this paper is that the present crisis situation in the area of public health does not necessarily mean an analogous crisis in economic sphere, which is the sign neoliberal capitalism. We claim that the situation of pandemic harmonizes with capitalist economy. In effect the system appears as stable and effective.

In our article we present dialectical view of ideological aspects of pandemic reality, which corelates with theorem about socialization of losses and privatization of profits in economic and political processes.

Keywords: neoliberalism; shock doctrine; surveillance capitalism; Covid-19; gender; social inequality

* Uniwersytet Opolski, Instytut Nauk o Polityce i Administracji.

** Uniwersytet Opolski, Instytut Nauk o Polityce i Administracji. 


\section{WSTĘP}

Monika Kostera, badaczka zarządzania, i Jarosław Niemiec, działacz związkowy, chcąc opisać społeczne skutki podziału procesu pracy, charakterystycznego dla epoki społeczeństw przemysłowych, przywołują postać z filmu Charliego Chaplina Modern Times. Robotnik, w którego wciela się Chaplin, pracuje przy taśmie produkcyjnej, wykonując wąski zakres ściśle powtarzanych czynności zgodnie $\mathrm{z}$ wizją tzw. naukowego zarządzania, której ojcem jest Frederick Taylor, a która w późniejszym czasie jest rozwijana pod postacią fordyzmu. Po ustaniu pracy robotnik nie jest w stanie przestać wykonywać wyuczonych ruchów (Kostera, Niemiec, 2020). Przytoczony przez Kosterę i Niemca obraz jest jaskrawym opisem bezrefleksyjnego z konieczności przyswojenia odpowiednio wykonywanych gestów, które - mimo że pozornie efektywne pod względem niskich kosztów ekonomicznych - prowadzą robotnika do stanu otępienia. W ten sposób Chaplin w swoim filmie przeprowadza krytykę alienującego procesu organizacji pracy.

Opis ten nie traci na swej aktualności w obecnym kontekście ery neoliberalnej, czy też - jak można to inaczej określić - w obecnej fazie późnego kapitalizmu. Niemniej, przyglądając się kondycji współczesnego społeczeństwa i formom procesu pracy, zbliżamy się do wniosku, że problemy z tym związane, w tym przede wszystkim alienacja, zyskują nowe oblicza. Wobec czego bardziej trafnym filmowym opisem tej rzeczywistości będzie nie tyle Chaplinowski robotnik w „żelaznej klatce” (Sennett, 2010), połykany przez potężne koła zębate, lecz kurier, bohater obrazu Kena Loacha Nie ma nas w domu (2019). To już nie robotnik fabryczny, ale pracownik autonomiczny, samodzielnie zarządzający własnym czasem, indywidualnie odpowiedzialny, pozbawiony bezpośredniego nadzoru i ochrony instytucjonalnej. Jako samozatrudniony jest zmuszony do ciągłego wywiązywania się z dostarczania przesyłek w nieokreślonym dziennym czasie pracy. Ów kurier, powodowany wymuszoną elastycznością, pozostaje w nieustannym kreatywnym ruchu, podczas gdy bezruch lub niedostatecznie kreatywne rozwiązywanie pojawiających się problemów jest równoznaczne z niezarabianiem. Kryzysowe sytuacje dlań, jak np. incydent pobicia, nie oznaczają paraliżu pracy, a tylko konieczny przystanek, stając się ledwie kolejnym wyzwaniem mobilizującym do dalszego „dawania sobie rady”.

Powyższy opis czytany przez pryzmat od ponad roku panującej pandemii zdaje się być dobrym wstępem do zadania pytań, odnoszących się do dyskursów wokół kryzysów systemu, jego rozpadu, recesji, zapowiedzi końca realiów 
wymiany ekonomicznej, jakie są nam zapowiadane. Ostatni rok obfitował w tego rodzaju zapowiedzi, co jest symptomatyczne w obliczu sytuacji kryzysowej, dotąd niedoświadczanej w warunkach obecnego rozwoju mediów.

Twierdzimy, że obecna sytuacja kryzysowa w zakresie zdrowia publicznego nie musi oznaczać analogicznego kryzysu współczesnego nam kapitalizmu neoliberalnego. Co więcej, ekstremalny charakter pandemicznej sytuacji i wymuszone przez nią nagłe społeczne zmiany i indywidualne strategie współgrają $\mathrm{z}$ roszczeniami, jakie system wysuwa wobec jednostek. Wobec czego system jawi się jako stabilny, a nawet efektywny, co wynika ze zdolności adaptacyjnych, stanowiących jądro neoliberalizmu i wypracowanej przezeń rządomyślności i promowania „zarządzania sobą”. W rezultacie zyskujemy dialektyczny (Such, 1992) obraz ideologicznego charakteru pandemicznej rzeczywistości, przepełnionej paradoksami i urządzanej w duchu uspołecznienia kosztów i prywatyzacji zysków (Mazzucato, 2016).

Konwencja, będąca zarazem metodą, jaką chcemy się posłużyć, odwołuje się do fresku, jednakże nie socjologicznego, a politologicznego, czy wręcz teoriopolitycznego. Jak określa to Jan Strzelecki, gatunek ten charakteryzuje się natłokiem sylwetek, zdarzeń i interpretacji (Riesman, 2016). Chcemy przyjrzeć im się przez pryzmat elementów krytycznej analizy dyskursu. Język, a zatem i opis, a w dalszej perspektywie kształtowanie rozmaitych form doświadczania, przeżywania rzeczywistości społecznej, politycznej i ekonomicznej, stanowi praktykę społeczną. Praktyka społeczna z kolei zakłada dialektyczną relację pomiędzy wydarzeniem dyskursywnym a sytuacjami, instytucjami, strukturą społeczną - dyskurs je kształtuje, ale i sam jest przez nie kształtowany. Ze względu na te cechy pojawia się uzasadnione pytanie o ideologiczny charakter dyskursu, jego przesłanek i skutków, w tym reprodukcję relacji władzy pomiędzy różnymi grupami społecznymi (Fairclough, Wodak, 2006).

\section{PANDEMICZNY SZOK I NEKROPOLITYCZNA REAKCJA}

Cytowany przez Naomi Klein w Doktrynie szoku czołowy neoliberalny ekonomista, Milton Friedman, zauważył nader trafnie: „Tylko kryzys - rzeczywisty lub postrzegany - prowadzi do realnych zmian. Kiedy taki kryzys nastąpi, rodzaj podejmowanych działań będzie zależał od tego, jakie pomysły dominują na rynku idei. I tutaj właśnie dostrzegam nasze najważniejsze zadanie. Musimy stwarzać alternatywy dla istniejących rozwiązań, mówić o nich i utrzymywać je 
przy życiu, aż pewnego dnia to, co politycznie niemożliwe, stanie się politycznie nieuniknione" (Klein, 2016).

Epoka nowoczesna, powtórzmy za J. R. Benigerem, to era „rewolucji kontroli”, kompleksowych zmian technologicznych i ekonomicznych w zakresie tego, jak informacja jest zbierana, przechowywana i komunikowana, co pociąga za sobą decyzje, które mogą wpływać na kontrolę społeczną (Beniger, 1986). Na obecnym etapie procesu dziejowego mamy do czynienia ze zjawiskiem „kapitalizmu inwigilacji”. Dla Shoshany Zuboff jest to m.in. „Pasożytnicza logika ekonomiczna, w której wytwarzanie towarów i usług jest podporządkowane nowej globalnej architekturze modyfikacji behawioralnych” i „Niegodziwa mutacja kapitalizmu naznaczona koncentracją bogactwa, wiedzy i władzy, niespotykana w historii ludzkości” (Zuboff, 2020). Mechanizmy inwigilacji na bezprecedensową skalę są nieustannie rozwijane i stają się coraz bardziej wysublimowane (Czapnik, Baraniewicz-Kotasińska, 2019).

Wbrew tezie Manuela Castellsa o informacjonizmie, jaki miałby zastąpić kapitalizm, kapitalizm nadzoru jest kapitalizmem per se, czyli systemem prywatnej akumulacji kapitału i wyzysku. Jak zauważył przed dekadą Mark Andrejevic, wyzysk to wydobycie bezpłatnej, wymuszonej i wyalienowanej pracy. Ta kategoria może być zastosowana do różnych form nieodpłatnej, lecz generującej zyski aktywności online - komercyjny monitoring podwaja świadomą, intencjonalną aktywność użytkowników. Nowe formy inwigilacji są formą władzy, która próbuje zarządzać i kontrolować zachowanie konsumentów (Andrejevic, 2011).

Od wielu lat pojawiają się w debacie naukowej i medialnej obawy, że dane gromadzone przez cyfrowych gigantów zagrażają prywatności użytkowników. Informacje, jakie dobrowolnie umieszczamy o sobie w mediach społecznościowych, mogą być wykorzystywane przy wpływaniu na nasze zachowania, w tym decyzje wyborcze (po skandalu wokół firmy Cambridge Analytica zdaje się to nie ulegać wątpliwości). Poza sporem pozostaje, że mobilne technologie internetowe i wielkie zbiory danych (Big Data) dają wręcz nieograniczone możliwości śledzenia poczynań jednostek w nieomal każdej sekundzie ich życia.

Cyfrowi giganci z Doliny Krzemowej przekonują o swoim dobroczynnym wpływie na społeczeństwo. Nieustannie podkreślają, że nie powinno ich się obwiniać o wszelkie negatywne aspekty bycia online - podobnie jak amerykańska telewizja komercyjna przed laty, bronią się, mówiąc, że dają tylko ludziom to, czego oni pragną. Innymi słowy, dolary, funty czy juany satanisty i religijnego fundamentalisty ważą tyle samo, im obu należy się pożądany towar, który zaspokoi ich oczekiwania (Drwęski, 2019). Niekiedy ten towar powinien być 
oznaczony przestrogą podobną do tej na paczce papierosów („Palenie zabija”): biały supremacjonista, który w marcu 2019 zabił 51 osób w nowozelandzkim Christchurch, strzelając do muzułmanów w dwóch meczetach - jak ujęto to w prawie 800 -stronicowym oficjalnym raporcie - zradykalizował się przez YouTube'a i Facebooka (D’Anastasio, 2020). Jest rzeczą dobrze udokumentowaną, że algorytmy YouTube’a podsycają ekstremizm (Ribeiro i in., 2020).

Jeden z właścicieli Google’a, Eric Schmidt, jeszcze przed pandemią ostrzegał na łamach New York Timesa przed niebezpieczeństwem, że w latach trzydziestych XXI wieku Chiny będą miały większą gospodarkę od amerykańskiej, więcej będą wydawać na badania i rozwój, szerzej od Stanów Zjednoczonych będą używać technologii komputerowych, będą posiadać lepszą infrastrukturę technologiczną. Jedynym rozwiązaniem, wedle Schmidta, jest znaczące zwiększenie funduszy publicznych, włącznie z funduszami dla Departamentu Obrony. Opowiedział się on za koniecznością rozwijania partnerstw publiczno-prywatnych (Schmidt, 2020).

Schmidt z czasem dokonał rebrandingu swych żądań, twierdząc, że ich spełnienie jest koniecznością w obliczu pandemii. Korporacje technologiczne zaczęły kreować się na opiekunów zdrowotnych, przekonując, że ich wpływ na społeczeństwo jest zbawienny. Kryzys okazał się dla nich szansą na permanentną transformację. Wyuczona nieodpowiedzialność gigantów technologicznych - na której zarabiają oni setki miliardów dolarów - ma pójść w niepamięć w obliczu konkurencji z autorytarnymi Chinami, które inwestują w sztuczną inteligencję czy infrastrukturę cyfrową.

Żyjemy w laboratorium przyszłej rzeczywistości, w której wyeliminuje się fizyczną bliskość między ludźmi, zapewniając ogromne zyski korporacjom technologicznym. Jak ujmuje to Klein (2020), domy przestaną być naszą przestrzenią prywatną, zamieniając się w szkoły, sale ćwiczeń, gabinety doktorskie, a nawet jeśli państwo tak postanowi - nasze więzienia. Rzekomo nasza przyszłość będzie sterowana przez „sztuczną inteligencję”, lecz tak naprawdę będzie okupiona ciężką pracą harujących w magazynach, centrach danych, miejscach moderowania internetowych treści, elektronicznych „fabrykach potu” (sweatshops), kopalniach litu, przemysłowych farmach, więzieniach, w których robotnicy są narażeni na choroby i hiperwyzysk. W nowym wspaniałym świecie każdy nasz ruch, każde nasze słowo, każda nasza relacja mogą być śledzone, umieszczane i przetwarzane w wielkich centrach danych $\mathrm{w}$ ramach bezprecedensowej współpracy pomiędzy rządem i gigantami technologicznymi (Klein, 2020).

Cyfrowy kapitalizm, zauważa Daniel Møller Ølgaard (2020), jest nie tylko nową metodą akumulacji kapitału, lecz logiką rządzenia, zaadoptowaną przez 
coraz bardziej neoliberalne demokracje. W jego ramach postępuje utowarowienie danych cyfrowych, kluczowe znaczenie mają prywatno-publiczne partnerstwa, których celem jest poznanie i manipulowanie zachowaniami konsumentów i obywateli. Tu pojawia się budząca wątpliwości obietnica, że usługi i produkty sprzedawane przez wielkie korporacje technologiczne są jedyną szansą na zastopowanie pandemii, uczynienie nas i naszych bliskich bezpiecznymi. Cyfrowy kapitalizm i związany z nim sposób produkcji wiąże się z fizycznym, kulturowym i społecznym podziałem na konsumentów towarów cyfrowych i niezliczoną liczbę kurierów, moderatorów, górników i robotników (a częściej - robotnic) przy fabrycznej taśmie produkcyjnej, którzy wytwarzają nasze urządzenia technologiczne i cyfrowe towary. Następuje relokacja przemocy i ucisku z bogatych zachodnich krajów do państw postkolonialnych (Møller Ølgaard, 2020).

Tu pojawia się ważki wątek klasowy. Rodzi się pytanie, jak można mówić o fizycznym dystansowaniu się - wskazanym, aby osłabić transmisję koronawirusa - w świecie, w którym około miliarda ludzi żyje w warunkach slumsów. Wedle danych Światowej Organizacji Zdrowia dwie piąte globalnej populacji, czyli około 3 miliardów ludzi, nie ma w domu możliwości umycia rąk (Christian Aid, 2020). Ów brak dostępu do podstawowych dobrodziejstw cywilizacji ma wymiar nekropolityczny, definiujący suwerenność w skali świata. Jak zauważa Achille Mbembe, ostatecznym wyrazem suwerenności jest władza i możliwość dyktowania, kto może żyć, a kto musi umrzeć. Zabijanie lub zgoda na życie konstytuuje granice suwerenności. Sprawowanie suwerenności oznacza kontrolowanie śmiertelności i definiowanie życia jako przejawu władzy (Mbembe, 2003).

Ludzie biedni - co w wielu krajach ma wymiar rasowy i etniczny, stanowiąc wyraz urasowienia populacji (Turowski, 2015) - są szczególnie narażeni na śmierć z powodu Covid-19. Dokładnie widać to na przykładzie Nowego Jorku - mieszkańcy bogatszych dzielnic pracowali zdalnie, niekiedy wyprowadzając się z miasta, a jeśli zostawali, to żywność dostarczano im bezpośrednio do domów. Ubożsi nowojorczycy - ci choćby, którzy dostarczają majętnym jedzenie czy ich pielęgnują w potrzebie - znacznie częściej zapadali na koronawirusa. Mieszkańcy Bronxu, czyli głównie Afroamerykanie i Latynosi - dwa razy częściej umierali na Covid-19 niż nowojorczycy en bloc, co ściśle wiązało się z ich ubóstwem (Pilkington, Rao, 2020).

Doświadczenie brytyjskie wskazuje, że pandemia znacznie silniej od pozostałych grup dotknęła czarnych, Azjatów i przedstawicieli klasy robotniczej. Wedle Mirki Madianou, technologie cyfrowe i praktyki danych w odpowiedzi na Covid-19 wzmocniły nierówności społeczne, już uprzednio istniejące 
w społeczeństwie, wiodąc do kolejnej katastrofy, tym razem stworzonej przez człowieka, więżąc ludzi w stanie niepewności i chwiejności. Ta druga katastrofa wiąże się z używaniem technik zdalnego nauczania i pracy na odległość, a także sposobem funkcjonowania służby zdrowia. Wiele technologii, takich jak aplikacje śledzące kontakty, może być użytych dla innych celów, normalizując inwigilację, która tradycyjnie dotykała marginalizowane społeczności. Outsourcing cyfrowej służby zdrowia konsoliduje pojawienie się sprywatyzowanego cyfrowego państwa dobrobytu, z czym wiąże się wzrost ryzyka wyłonienia się praktyk dyskryminacyjnych (Madianou, 2020).

Wszystko wskazuje na to, że pandemia koronawirusa będzie kolejną katastrofą, jaką wykorzysta kapitalizm, aby poszerzać swoje granice (Burns, 2020), przy czym nie sposób wykluczyć, że żywiący się strachem (Gürcan, Ömer Ersin, 2020) wirus neoliberalizmu może przynieść więcej szkód aniżeli Covid-19 (Szwabowski, Wiecław, 2021). Tym ważniejsze jest, aby humanistyka nie ulegała cyfrowemu złudzeniu dobroczynnego wpływu gigantów technologicznych także w czasie pandemii - i była konsekwentnie wolnościologia (Bauman, Czapnik, 2016), badając wszelkie przejawy zniewolenia.

\section{PANDEMICZNA POCHWAŁA KREATYWNOŚCI}

Elastyczność jako jedna z podstaw „konsensusu waszyngtońskiego” stała ważną częścią dominującej doktryny polityki ekonomicznej. Nie jest zatem dziełem przypadku, iż to właśnie założenie o koniecznej elastyczności w sferze społecznej aktywności ekonomicznej zapewnia owej doktrynie swoistą ciągłość, pomimo chwilowych przeszkód. Jednocześnie zaś towarzyszy temu rozwój branż kreatywnych i dyskursu waloryzacji kreatywności jako cechy pożądanej we współczesnej gospodarce, również na poziomie jednostkowym. Taka sytuacja ma swoje konsekwencje społeczne w kontekście obecnego kryzysu zdrowotnego. Zarazem jednak wspomniany dyskurs efektywnie sprzyja podtrzymaniu stabilności systemu. W celu analizy ideologicznego charakteru kreatywności, w tym kreatywności na poziomie indywidualnych strategii, warto pochylić się nad elementami emergencji sfery społeczno-ekonomicznej. Wielkie procesy społeczno-ekonomiczne, a takim jest pandemia i zjawiska, jakie uruchomiła, nie pozostają bez wpływu na indywidualne biografie (Mills, 2007), w które zostaje wpisane oczekiwanie elastyczności, świadczącej o zdolności przetrwania. 
Trafnie tę problematykę dekonstruował Jakub Barszczewski w swojej pracy Przymus kreatywności jako źródło cierpień (2016) pod kątem organizacji pracy i zarządzania w postfordyzmie. „Nowy duch kapitalizmu”, odwołując się do osobistych aspiracji jednostki, czyni krytyki przemysłowego kapitalizmu opartego na fordyzmie częścią ideologii swej nowej formy - neoliberalnej. Emancypacyjne postulaty tych krytyk, takie jak niezależność, samorealizacja, oddanie pasji, stały się częścią programów zarządzania, w ramach których możliwe stało się eksploatowanie „kapitału ludzkiego” poprzez zaangażowanie w pracę (Barszczewski, 2016). Niemniej analityczny potencjał uwag Barszczewskiego wykracza poza problematykę zarządzania. Unaoczniają one bowiem przeniesienie kosztów przetrwania systemu na jednostki, a także „rozbrojenie” roszczeń wobec tegoż systemu i postrzeganie jego strukturalnych problemów jako problemów do kreatywnego rozwiązania.

Jako odpowiedź na tak postawione przed jednostką zadania rozpatrywany jest coaching. Michał Mokrzan analizuje tę usługę w konstelacji klasa-kapitał-coaching. Autor argumentuje, iż coaching jako instrument neoliberalnego urządzania służy wytwarzaniu emocjonalnej formy kapitału kulturowego (Mokrzan, 2019). Celem samego coachingu jest - deklaratywnie - osiągnięcie dobrostanu emocjonalnego, który w późnym kapitalizmie jest nie tyle wyrazem troski o kondycję emocjonalną, a raczej zdolnością do produktywnego funkcjonowania w tych warunkach systemowych (Mokrzan, 2019). Jakkolwiek Mokrzan swoje analizy przede wszystkim odnosi do wyższej klasy średniej, to można dostrzec ich uniwersalność w sensie aspirujących wzorców i stylów życia. Można stwierdzić zatem, iż w obecnych warunkach odbywa się swoisty seans coachingu samych siebie. Celem tego procesu jest utrzymanie efektywności własnego życia.

Wobec powyższego w pandemicznych okolicznościach waloryzowane jest pomysłowe, a zatem kreatywne poradzenie sobie. Oznacza to przede wszystkim obowiązek produktywności. Przejawia się on w podejmowaniu nierzadko abstrakcyjnych aktywności zarobkowych, co sprawia, że jednostki zyskują szacunek w oczach społecznych obserwatorów. Wywiązywanie się ze swej roli podmiotu zarabiającego materializuje neoliberalną racjonalność, której postulatem jest utożsamienie odpowiedzialnej i moralnej jednostki z jednostką racjonalną ekonomicznie (Lemke, 2010, Mokrzan, 2019). W ten sposób w praktyce egzemplifikuje się kategoria urządzania - jako moralne zobowiązanie do stania się przedsiębiorcami siebie. Na poziomie budowy ideologicznego wyobrażenia swego funkcjonowania w społeczeństwie następuje ekonomizacja relacji społecznych, włącznie ze stosunkiem do samych siebie (Mokrzan, 2019). 
W konsekwencji kryzysowa sytuacja - sytuacja zagrożenia zdrowia, nie stwarza możliwości zaprzestania aktywności ekonomicznej.

Ilustrując powyższą argumentację, warto przywołać obrazy medialne. Przykład, który był mocno obecny w przestrzeni medialnej, dotyczy aktora teatralnego i telewizyjnego Marcina Januszkiewicza. Ze względu na wprowadzenie obostrzeń epidemicznych i zawieszenie działalności placówek kultury i planów filmowych aktor stracił źródło swoich dochodów, w związku z czym podjął pracę jako kurier. Jak sam to komentował: „Czas naprawdę wziąć się do roboty ludziska, znaleźć w sobie siłę, zahartować się w tej sytuacji. (...) Do roboty. Walczcie. O siebie i o swoich bliskich. I o pracę też. Póki ona jeszcze jest" (Polsat News, 2020). W wypowiedzi pojawia się konieczność podjęcia konfrontacji na własną rękę, gdy praca zarobkowa staje się jedyną formą przetrwania okresu restrykcji sanitarnych. Paradoksalnie to nie troska o zdrowie ma charakter priorytetowy w tym czasie, lecz konieczność ciągłego wytwarzania dóbr i usług. To częsty motyw poczucia winy z powodu chwilowego niewykonywania pracy i kultu pracy ponad własne siły spotykany w przestrzeni społecznej (Staśko, 2021). Opisana postawa aktora zyskuje szerokie uznanie, począwszy od mediów, a skończywszy na komentarzach pod doniesieniami na ten temat.

Na poziomie systemowym zwraca uwagę zjawisko, w ramach którego obserwujemy z jednej strony odejście od rygorystycznej polityki fiskalnej - wszak państwa w obliczu kryzysu i zapowiedzi kolejnych jego odsłon nie oszczędzają na wydatkach. Jednak drugą stroną tego medalu jest potęgujący się proces uberyzacji gospodarki (gig economy) w wyniku zjawisk wymuszonych przez pandemię (Szahaj, 2021). Konfrontacja tych dwóch elementów prowadzi do wniosku, iż rezygnacja z dyscypliny budżetowej przez państwa to nie tyle zwrot przeciwny wolnorynkowemu modeli gospodarowania, a raczej ukierunkowany na jego podtrzymanie. Jak powiada Andrzej Szahaj, zmiany strukturalne, które miałaby przeobrazić obowiązujące doktryny ekonomiczne, są wykluczone, co jest możliwe do wyczytania ze struktury interesów, jakie takimi zmianami byłyby zagrożone (2021).

Tezy wysunięte przez Szahaja znajdują potwierdzenie w danych, jakie zaczęły pojawiać się w przestrzeni publicznej. Ważną pozycją w tym względzie okazał się raport organizacji międzynarodowej Oxfam, zaprezentowany w styczniu 2021 roku: „Wirus nierówności” (The Inequality Virus). Jak pokazują autorzy raportu, w okresie pandemii, czyli od marca do grudnia 2020 roku, majątek miliarderów wzrósł o 3,9 bilionów dolarów, pogłębiając nierówności społeczne. To pogłębienie zresztą dotyczy nie tylko sfery ekonomicznej. Przedstawiciele Oxfam nazwali 
nawet koronawirusa mianem „wirusa nierówności”. W raporcie podkreślono, iż grono najbogatszych osób na świecie nie odczuwa pogorszenia swego poziomu życia - zaledwie w dziewięć miesięcy trwania pandemii ich majątki powróciły do stanu sprzed pandemii. Zaś grupy i obszary najuboższe będą odrabiać zapóźnienia (nie tylko ekonomiczne, ale też np. edukacyjne) przez dekady (Oxfam, 2021). Z kolei nierówności są wyjątkowo spotęgowane ze względu na fakt, iż wzrosły w zasadzie we wszystkich krajach o różnym stopniu rozwoju (Oxfam, 2021). Teza, która najbardziej przebiła się w dyskursie publicznym, dotyczy jednak kalkulacji, iż majątek dziesięciu najbogatszych osób byłby w stanie zapewnić szczepionki przeciwko Covid-19 dla całego globu i zapobiec ubóstwu wynikłemu z pandemii (Oxfam, 2021).

Mark Lowcock, zastępca sekretarza generalnego ONZ ds. humanitarnych, napisał w przedmowie do raportu Global Humanitarian Response Plan: Covid-19 (April-December 2020): „Najnowsze szacunki sugerują, że nawet 6 tys. dzieci może umierać każdego dnia z przyczyn, którym można zapobiec, bezpośrednio lub pośrednio spowodowanych przez Covid-19. Przejmowanie środków przeznaczonych na ochronę zdrowia może podwoić liczbę śmiertelnych ofiar AIDS, gruźlicy i malarii. Zamykanie szkół obniży produktywność, zmniejszy dochody uzyskiwane przez całe życie i zwiększy nierówności. Spowolnienie wzrostu gospodarczego, wzrost bezrobocia i spadek frekwencji szkolnej zwiększają prawdopodobieństwo wojny domowej, która powoduje klęski głodu i wysiedlenia" (Achcar, 2020).

Powyższy stan rzeczy jest tragedią wtórną, wywołaną przez działania i zaniechania ludzi. Szacowany koszt ochrony najbiedniejszych 10 proc. ludzkości przed najgorszymi skutkami pandemii wynosi 90 miliardów dolarów, zatem mniej niż 1 proc. pakietu stymulacyjnego, który kraje bogate wprowadziły w celu ochrony swoich gospodarek (Achcar, 2020). O skali globalnych nierówności niech świadczy to, że gdyby pełen koszt tych działań poniósł sam Jeff Bezos, jego majątek nadal przekraczałby wartość 100 miliardów dolarów (\# 1 Jeff Bezos, 2021).

Gdy przyjrzeć się liście najbogatszych ludzi na świecie, to - poza faktem powiększenia majątków w okresie pandemii - zauważymy również, że aż trójka z nich (Bezos, Bill Gates, Mark Zuckerberg) swój majątek zgromadziła za sprawą wzrostu znaczenia technologii informacyjnych. Szahaj konstatuje, że to właśnie korporacje internetowe ujawniają w najwyższym stopniu swoje aspiracje i nie są one zainteresowane zmianą status quo. Pandemia wszakże zdecydowanie wzmocniła ich pozycje tworząc coś na kształt „kapitalizmu totalitarnego” (Szahaj, 2021, Zuboff, 2020), a stało się to między innymi za sprawą ogromnego 
wzrostu zapotrzebowania na ich usługi. Zrodziło ono się zarówno w wyniku uskuteczniania pracy zdalnej oraz upowszechnienia obrotu handlowego w sieci w związku z tzw. lockdownem.

Zarówno zatem na poziomie indywidualnym, jednostkowym, jak i poziomie systemowym, zdają się w praktyce testować typy idealne sformułowane przez Alaina Bihra które mają opisywać realia posfordowskie: fabryka płynna, fabryka elastyczna, fabryka rozproszona. Pierwszy oznacza zachowanie ciągłości produkcji, bez przestojów. Drugi oznacza dostosowanie procesów wytwarzania do zmienności procesu wymiany. Trzeci z kolei wiąże się z dekoncentracją produkcji (Bihr, 2008).

\section{GENDEROWY ASPEKT STANU PANDEMII}

Życie jednostki jest kształtowane przez społeczne procesy klasowe, a także procesy genderowe w tym społeczeństwie. W gruncie rzeczy to, jak ludzie produkują, pozyskują i dystrybuują wartość dodatkową pracy zależy od tego, jak produkują, dystrybuują i odbierają definicje tego, co znaczy być mężczyzną lub kobietą (Fraad i in., 2009).

Wymuszone poprzez odgórne decyzje polityczne radykalne zmiany organizacji życia osobistego i zawodowego, jak w przypadku analizowanych powyżej kwestii, wywołują pytanie o znaczenie płci w kontekście panującej pandemii. Przydatne bardziej niż kiedykolwiek zdają się tutaj być takie kategorie jak: „praca reprodukcyjna”, „niewidzialna praca”. Pochodzą one z feministycznej teorii politycznej i pozwalają na opis polityczności w sferze osobistej, a ta wobec pandemii stała się ciekawym przedmiotem obserwacji. Analogicznie do uwag na temat kreatywności i zarządzania, i te pojęcia służą opisowi procesów przenoszenia obciążeń wynikłych z odtwarzania kapitalistycznego systemu produkcji.

Jak nigdy wcześniej, poza okresem dotkliwych kataklizmów, ochrona już nie tylko zdrowia, ale i życia stanęła w centrum życia politycznego, w tym współczesnego państwa i tych wszystkich procesów, które od niego współzależą, a więc także wymiany rynkowej. Zwłaszcza życie ekonomiczne prawdopodobnie pierwszy raz w historii kapitalizmu zwolniło na taką skalę wobec zagrożenia zdrowia publicznego. „Pandemia koronawirusa zmusza kapitalizm do tymczasowego wysunięcia życia na pierwszy plan”, zauważa Tithi Bhattacharya i dodaje, że: „Jednak kapitał niechętnie poświęca jakąkolwiek część swoich zysków na reprodukcję życia. Dlatego też w kapitalizmie wszelka praca opiekuńcza jest 
dewaluowana (...)” (Bhattacharya, 2020b). Praca ta jest „powierzana” na ogół kobietom, pozostając nierzadko niezauważaną społecznie, o niskim prestiżu. Co więcej, duża jej część przybiera formę nieodpłatnej pracy reprodukcyjnej wykonywanej w domu - jako matki, żony, córki.

Znaczenie tego rodzaju pracy rośnie w okresie społecznej izolacji wymuszonej pandemią. Jak stwierdzają Agata Dziuban i Zuzanna Dziuban: „Reprodukcja życia - w sensie dosłownym i jako, nisko waloryzowanej i opłacanej, pracy reprodukcyjnej - w coraz większym stopniu spada na obywateli i obywatelki" (Dziuban, Dziuban, 2020). Autorki trafnie diagnozują sytuację. Niemniej jednak z perspektywy kilkunastu miesięcy funkcjonowania w epidemicznych obostrzeniach można stwierdzić, iż w większym stopniu obciążenie te dotknęło kobiety.

Potwierdzają to dane opublikowane przez Parlament Europejski. Odnotowuje to także między innymi raport Komisji Europejskiej oraz wspomniany raport Oxfam. Chcąc, przynajmniej wstępnie uporządkować problem pracy reprodukcyjnej kobiet, należy zwrócić uwagę, że jest ona wykonywana dwutorowo, nierzadko jednocześnie: w ramach pracy zarobkowej i w ramach pracy nieodpłatnej. W przypadku pierwszego zagadnienia jest to praca słabo opłacana i/lub o niskim prestiżu społecznym. Jej zakres jest specyficzny, ponieważ profesje te odwołują się do troski, empatii, poczucia obowiązku. To sektory związane z szeroko rozumianą opieką (w tym zdrowotną), dbałością o porządek, obsługą $\mathrm{w}$ handlu i innych usługach. Te sfeminizowane sektory gospodarki zaliczają się do tych, które w najwyższym stopniu są obciążone walką z pandemią. Aż 76 proc. pracowników opieki zdrowotnej w Unii Europejskiej stanowią kobiety, 95 proc. osób sprzątających i pomocy domowych, 93 proc. osób sprawujących opiekę nad dziećmi, 82 proc. obsługi kasowej. Łącznie zaś to 84 proc. osób zatrudnionych w sektorach dotkniętych pandemią. W związku z czym, w zakresie pracy zarobkowej zostały one znacznie narażone na niepewność (Parlament Europejski, 2021). Oznacza to, że kobiety nie tylko w niniejszych okolicznościach są w większym stopniu narażone zdrowotnie, lecz także w większym stopniu obciążone pracą zawodową, np. w mocno sfeminizowanym zawodzie nauczycielskim, który wymagał adaptacji do pracy zdalnej.

W przypadku drugiego zagadnienia mowa o obszarze, który jest przez Parlament Europejski nazwany „sektorem gospodarki nieformalnej”. Chodzi o pracę w gospodarstwie domowym. W samej Unii Europejskiej ze względu na tego rodzaju zaangażowanie wykluczonych $\mathrm{z}$ aktywności zawodowej jest nieco ponad 32 proc. kobiet, podczas gdy mężczyźni w podobnym położeniu to niespełna 5 proc. (Parlament Europejski, 2021). 
Cedowana na kobiety odpowiedzialność za gospodarstwo domowe, w tym odpowiedzialność opiekuńcza w okresie pracy i nauki zdalnej, pozwala na prywatyzowanie odpowiedzialności i kosztów - ekonomicznych i psychicznych. To podtrzymywanie produktywności innych jednostek z jednej strony i odciążenie instytucji społecznych z drugiej (Martínez, 2020). W tym kontekście eksploatowana jest empatia, która kulturowo jest przypisywana kobietom, a także fakt, iż kobiety - również ze względu na odpowiedzialność opiekuńczą - nie zawsze doświadczają możliwości odmowy wykonywania danej pracy, częściej bowiem są narażone na jej utratę. Dotyczy to zwłaszcza kobiet z niższych klas społecznych. W rezultacie możliwość ochrony własnego zdrowia, troski o bliskich, jest zdeterminowana przez stosunki pracy, które stanowią punkt odniesienia dla współczesnej polityki (Bhattacharya, 2020a).

Jak zauważa Harriet Fraad (2009), „Praca emocjonalna (emotional labor) jest wydatkowaniem czasu, wysiłku i energii, wykorzystywaniem mózgu i mięśni, aby zrozumieć i zaspokoić potrzeby emocjonalne". Przez potrzeby emocjonalne rozumie ona ludzkie potrzeby uczucia bycia chcianym, cenionym, kochanym i otoczonym troską. Emocjonalne potrzeby jednostek często są niewysłowione czy też nieznane/nieświadome. Praca emocjonalna często występuje wraz z pracą fizyczną - produkcją fizycznych dóbr i usług - lecz praca emocjonalna różni się od pracy fizycznej, jej celem bowiem jest wyprodukowanie specyficznych uczuć bycia chcianym, cenionym, kochanym i/lub otoczonym troską (Fraad, 2009).

Nie sposób wyobrazić sobie adekwatnie funkcjonującego społeczeństwa bez ogromu nieopłacanej - zwykle kobiecej - pracy emocjonalnej. W pandemii jej znaczenie jeszcze wzrosło, gdyż zwiększyła się presja emocjonalna na poszczególnych członków rodziny, nie wspominając o takich zjawiskach godnych ubolewania - i społecznej próby wykorzenienia, a przynajmniej maksymalnego ograniczenia - jak przemoc domowa. ONZ Kobiety przestrzegała już na wczesnym etapie pandemii koronawirusa przed wzrostem o kilkadziesiąt procent aktów przemocy przeciwko kobietom i dziewczętom, która już przed rozprzestrzenianiem się Covid-19 dotykała prawie ćwierć miliarda osób (UN Women, 2020). 


\section{WNIOSKI}

Trwająca pandemia uwypukliła sprzeczność pomiędzy światem życia a światem gospodarki. Stała się ona treścią piętrzących się dylematów procesów decyzyjnych zapadających w gabinetach polityków, co było widoczne w wypowiedziach decydentów. Aleksander Temkin przywołuje jedną z nich: wiceguberantor Teksasu, który stwierdza, iż jest gotów umrzeć za gospodarkę i sądzę, że wielu starszych ludzi także (Temkin, 2021). Okazało się bowiem, iż realna ochrona kondycji jednej ze stron tej sprzeczności jest możliwa tylko w sytuacji zawieszenia aktywności drugiej. W rezultacie obserwujemy w obszarze państw i Unii Europejskich przeciąganie linii pomiędzy jedną a drugą stroną. Jak zwraca uwagę Temkin, w tym starciu zdecydowanie większą siłę przebicia ma świat kapitału, transfery finansowe w znacznej części nie są bowiem skierowane do zwykłych ludzi. Rodzi to poczucie zerwania umowy społecznej z państwem, a w efekcie prowadzi do przyjęcia czegoś na kształt darwinizmu społecznego (Temkin, 2021).

Nie sposób zaprzeczyć, że kapitalistyczna reakcja na pandemię koronawirusa w całej rozciągłości potwierdza wzmocnienie zjawiska zwanego - skądinąd niezbyt szczęśliwie - przez Klein korporacjonizmem: „Do jego głównych cech należy zaliczyć: transfer znacznej części publicznych zasobów w prywatne ręce korporacji, czemu nierzadko towarzyszy zadłużenie państwa na olbrzymią skalę; stałe powiększająca się przepaść w dochodach pomiędzy bajecznie bogatą elitą społeczeństwa i resztą zbędnych, ubogich obywateli oraz agresywna retoryka nacjonalistyczna, która służy usprawiedliwieniu ciągle rosnących wydatków na bezpieczeństwo. Z punktu widzenia korporacyjnych elit, które są głównym beneficjentem powstałego systemu, trudno wyobrazić sobie bardziej korzystny sposób organizowania społeczeństwa” (Klein, 2016).

Nie sposób wykluczyć, że Covid-19 przyśpieszy (jeśli już nie przyśpieszył) wyłonienie się nowego - acz, bezsprzecznie, nadal kapitalistycznego - porządku, który zastąpi neoliberalizm jako zasadę organizacji systemowej. Jeśli - idąc intuicją Sławomira Mrożka z opowiadania Lew - orientować się na to, co nowe, co kiełkuje, to można mieć daleko idące obawy, że nowy porządek będzie o wiele bardziej autorytarny. Wydaje się, iż tylko metodami antydemokratycznymi współczesny kapitalizm może rozwiązać swoje narastające sprzeczności, w tym wyzwanie ze strony chińskiej gospodarki rynkowej z komunistyczną nadbudową monopartii, a także pogłębiające się nierówności - między państwami i wewnątrz nich. 
Mimo procesu automatyzacji i robotyzacji - a może, paradoksalnie, także dzięki nim - coraz większym problemem, zauważa Tadeusz Klementewicz, będzie „rozdźwięk między społecznym charakterem procesów gospodarczych a prywatnym przywłaszczaniem wytworzonego bogactwa społecznego, czyli w kanonie: sprzeczność między pracą a kapitałem. Każdy bowiem produkt jest wytworem wspólnej pracy wielu ludzi, także minionych pokoleń" (Klementewicz, 2015). Korporacje technologiczne potrafią w sposób nader wysublimowany prywatyzować zyski i uspołeczniać straty, co czasy pandemii w pełni uwypuklają.

\section{BiBLIOGRAFIA:}

„\#1 Jeff Bezos”. (2021). Forbes, 21 kwietnia. Pobrane z: https://www.forbes.com/profile/ jeff-bezos/?sh=63547b801b23.

Achcar, G. (2020).,,Wielka kwarantanna” pustoszy Trzeci Świat. Le monde diplomatuque - edycja polska, 6, 10-12.

Andrejevic, M. (2011). Surveillance and alienation in the online economy. Surveillance \& Society, 8(3), 278-287.

Barszczewski, J. (2016). Przymus kreatywności jako źródło cierpień. Życie i praca w obliczu neoliberalnej polityki zarządzania. Gdańsk: Wydawnictwo Naukowe Katedra.

Bauman, Z., Czapnik, S. (2016). Jak słowo ciałem uczynić. Z Zygmuntem Baumanem rozmawia Sławomir Czapnik. Studia Krytyczne/Critical Studies, 2, 8-20.

Beniger, J. R. (1986). The Control Revolution: Technological and economic origins of the Information Society. Cambridge, MA: Harvard College.

Bhattacharya, T. (2020a). Dlaczego potrzebujemy Teorii Reprodukcji Społecznej, by zrozumieć kryzys $w$ dobie koronawirusa? Pobrane z: https://www.praktykateoretyczna.pl/ artykuly/dlaczego-potrzebujemy-teorii-reprodukcji-spolecznej-zrozumiec-kryzysw-dobie-koronawirusa/.

Bhattacharya, T. (2020b). Koronawirus i praca opiekuńcza kobiet. Pobrane z: https:// www.praktykateoretyczna.pl/artykuly/koronawirus-i-praca-opiekuncza-kobiet/.

Bihr, A. (2008). Nowomowa neoliberalna. Retoryka kapitalistycznego fetyszyzmu. Warszawa: Instytut Wydawniczy Książka i Prasa.

Burns, R. (2020). A COVID-19 panacea in digital technologies? Challenges for democracy and higher education. Dialogues in Human Geography, 10(2), 246-249. DOI: $10.1177 / 2043820620930832$.

Christian Aid. (2020). Building back with justice: Dismantling inequalities after Covid-19. July 2020. London: Christian Aid.

Czapnik, S., Baraniewicz-Kotasińska, S. (2019). Surveillance in the liquid modern times. Studia Krytyczne/Critical Studies, 7, 11-23. DOI: 10.25167/sk.1105. 
D'Anastasio, C. (2020). The Christchurch shooter and YouTube's radicalization trap. Wired, 8 grudnia. Pobrano z: https://www.wired.com/story/christchurch-shooteryoutube-radicalization-extremism/.

Drwęski, B. (2019). Chaos, czyli nowa forma wojny światowej w erze globalizmu. Studia Krytyczne/Critical Studies, 8, 43-66. DOI: 10.25167/sk.2115.

Dziuban, A., Dziuban, Z. (2020). Warunkowanie wsparcie. Nekropolityka i solidarność $w$ dobie kryzysu. Pobrane z: https://biennalewarszawa.pl/warunkowanie-wsparcianekropolityka-i-solidarnosc-w-dobie-kryzysu/.

Fairclough, N., Wodak, R. (2006). Krytyczna analiza dyskursu: wstępny opis. W: A. Jasińska-Kania, L. M. Nijakowski, J. Szacki, M. Ziółkowski (red.), Współczesne teorie socjologiczne, t. 2, (ss. 1047-1050). Warszawa: Wydawnictwo Naukowe Scholar.

Fraad, H. (2009). Toiling in the field of emotion. W: G. Cassano (red.), Class struggle on the home front: Work, conflict and exploitation in the household (ss. 137-151). Palgrave Macmillan, Basingstoke-New York.

Fraad, H., Resnick, S., Wolff, R. (2009). For every knight in shining armour, there's a castle waiting to be cleaned: A Marxist-feminist analysis of the household. W: G. Cassano (red.). Class struggle on the home front: Work, conflict and exploitation in the household (ss. 19-70). Basingstoke-New York: Palgrave Macmillan.

Gürcan, E. C., Kahraman, Ö. E. (2020). COVID-19 in historical perspective: How disaster capitalism fabricates a fear-managed world order. BRIQ, 1(3), 49-61.

Klein, N. (2016). Doktryna szoku. Jak wspótczesny kapitalizm wykorzystuje klęski żywiotowe i kryzysy społeczne. Warszawa: Warszawskie Wydawnictwo Literackie Muza SA.

Klein, N. (2020). How big tech plans to profit from the pandemic. The Guardian, 13 maja. Pobrane z: https://www.theguardian.com/news/2020/may/13/naomi-kleinhow-big-tech-plans-to-profit-from-coronavirus-pandemic.

Klementewicz, T. (2015). Stawka większa niż rynek. U źródeł stagnacji kapitalizmu bez granic. Warszawa: Książka i Prasa.

Kostera, M., Niemiec, J. (2020). Robota czy praca? Pobrane z: https://nowyobywatel. $\mathrm{pl} / 2020 / 10 / 13 /$ robota-czy-praca/.

Lemke, T. (2010). Biopolityka. Warszawa: Wydawnictwo Sic!

Madianou, M. (2020). A second-order disaster? Digital technologies during the COVID-19 pandemic. Social Media + Society July-September: 1-5. DOI: doi. org/10.1177/205630512094816.

Martínez, J. L. (2020) Koronawirus, kapitalizm i patriarchat: kto się teraz zajmie dziećmi? Pobrane z: https://www.praktykateoretyczna.pl/artykuly/koronawirus-kapitalizm-patriarchat/.

Mazzucato, M. (2016). Przedsiębiorcze państwo. Obalić mit o relacji sektora publicznego i prywatnego. Poznań: Wydawnictwo Ekonomiczne „Heterodox”.

Mbembe, A. (2003). Necropolitics. Public Culture, 15(1), 11-40.

Mills, C. W. (2007). Wyobraźnia socjologiczna. Warszawa: Wydawnictwo Naukowe PWN. Mokrzan M. (2019). Klasa, kapitat i coaching w dobie późnego kapitalizmu. Perswazja neoliberalnego urządzania. Toruń: Fundacja na Rzecz Nauki Polskiej. 
Møller Ølgaard, D. (2020). Reflections on Naomi Klein's Pandemic Shock Doctrine. E-International Relations, https://www.e-ir.info/2020/09/15/reflections-on-naomikleins-pandemic-shock-doctrine/.

Oxfam International. (2021). The Inequality Virus. Bringing together a world torn apart by coronvirus throught afair, just and sustainable economy. Summary. Pobrano z: https://www.oxfam.org/en. DOI: 10.21201/2020.6409.

Parlament Europejski. (2021). Wpływ pandemii COVID-19 na sytuację kobiet (infografiki). Pobrane z: https://www.europarl.europa.eu/news/pl/headlines/society /20210225STO98702/wplyw-pandemii-covid-19-na-sytuacje-kobiet-infografiki.

Pilkington, E., Rao, A. (2020). A tale of two New Yorks: pandemic lays bare a city's shocking inequities. The Guardian, 10 kwietnia. Pobrane $\mathrm{z}$ : https://www.theguardian. com/us-news/2020/apr/10/new-york-coronavirus-inequality-divide-two-cities.

Polsat News. (2020). Aktor stracił pracę przez koronawirusa. Zatrudnił się jako kurier. Pobrane z: https://www.polsatnews.pl/wiadomosc/2020-04-22/aktor-stracil-praceprzez-koronawirusa-zatrudnil-sie-jako-kurier/.

Ribeiro, M. H., Ottoni, R., West, R., Almeida, V. A. F., Meira, W. (2020). Auditing radicalization pathways on YouTube. $F A T^{\star}, 20$ : Proceedings of the 2020 Conference on Fairness, Accountability, and Transparency January 2020, 131-141. DOI: $10.1145 / 3351095.3372879$.

Riesman, D. (2016). Samotny tłum. Warszawa: Vis-á-vis Etiuda.

Schmidt, E. (2020). I used to run Google. Silicon Valley could lose to China. The New York Times, 27 luty. Pobrane z: https://www.nytimes.com/2020/02/27/opinion/ eric-schmidt-ai-china.html.

Sennett, R. (2010). Kultura nowego kapitalizmu. Warszawa: Warszawskie Wydawnictwo Literackie MUZA SA.

Staśko, M. (2021). Kult harówki to promocja niezdrowego trybu życia: braku snu, jedzenia i odpoczynku. Jestem jego ofiara. 11.04.2021. Pobrane z: https://wtv.pl/kult-harowki-to-promocja-niezdrowego-trybu-zycia-ms-110421?fbclid=IwAR3pU78KR6tK PMfTsiKyIoP-zw4_Mzq0yIIjtDpyFUapfq-WPH9ypHB07A4.

Such, J. (1992). Dialektyczne wizje świata. Warszawa-Poznań: Wydawnictwo Naukowe PWN.

Szachaj, A. (rozmowa przeprowadzona przez M. Michalaka). (2021). Jaki kapitalizm po pandemii? Prof. Andrzej Szachaj: Przegapiliśmy punkt bez odwrotu. Pobrane z: https://wydarzenia.interia.pl/raporty/raport-koronawirus-chiny/aktualnosci/ news-jaki-kapitalizm-po-pandemii-prof-andrzej-szahaj-przegapilism,nId,5079661.

Szwabowski, O., Wiecław, M. (2021). The Covid-Shock Doctrine: Under the tutorship of CoV-2, the voice(s) from Poland. Cultural Studies-Critical Methodologies, 21(2), 187-193. DOI: 0.1177/1532708620931144.

Temkin, A. (2021). Pieniądze za pandemię. Magazyn Kontakt, 11 kwietnia. Pobrane z: https://magazynkontakt.pl/pieniadze-za-pandemie.

Turowski, M. (2015). Granice rasy. Między nowym rasizmem a płynną rasologią. Studia Krytyczne / Critical Studies, 1, 111-130. 
UN Women. (2020). Covid-19 and ending violence against women and girls. Pobrane z: https://www.unwomen.org/-/media/headquarters/attachments/sections/library/ publications/2020/issue-brief-covid-19-and-ending-violence-against-women-andgirls-n.pdf?la=en\&vs=5006.

Zuboff, S. (2020). Wiek kapitalizmu inwigilacji. Walka o przyszłość ludzkości na nowej granicy władzy. Poznań: Wydawnictwo Zysk i S-ka. 